\title{
Anti-Bacterial Activity Of Ethanol Extract, N-Hexane Fraction, Ethyl Acetate Fraction And Water Fraction From Dragon Fruit Stem (Hylocereus Polyrhizus ) Against Methicillin-Resistant Staphylococcus aureus (MRSA)
}

\author{
Diah Arum Sari ${ }^{1}$, Indah Sulistyarini ${ }^{* *}$, Muhammad Ryan Radix Rahardian ${ }^{1}$ \\ ${ }^{1}$ STIFAR Yayasan Pharmasi Semarang, Indonesia \\ *corresponding author : indahsulistyarinistifar@gmail.com
}

\begin{abstract}
The stems of red dragon fruit (Hylocereus polyrhizus) are known to have several antibacterial compounds. The purpose of this study were to determine the antibacterial activity of ethanol extract, nhexane, ethyl acetate, and water fractions from dragon fruit stems on the growth of Methicillin-resistant Staphylococcus aureus (MRSA), and to determine the types of compounds that have antibacterial activity. Antibacterial activity was measured using wells and bioautography methods. Results showed that the highest antibacterial activity was found at a concentration of $30 \%$ both in the ethanol extract $(1.850 \mathrm{~cm}) ; \mathrm{n}$-hexane fraction $(1.948 \mathrm{~cm})$; ethyl acetate fraction $(1.640 \mathrm{~cm})$ and water fraction $(0.884 \mathrm{~cm})$ respectively. Meanwhile, the results of contact bioautography showed that the antibacterial compounds of Methicillin-resistant Staphylococcus aureus (MRSA) were flavonoids, saponins, and steroids.
\end{abstract}

Keywords: Dragon fruit stem, antibacterial, Methicillin-resistant Staphylococcus aureus (MRSA), Hylocereus polyrhizus.

\section{Introduction}

Staphylococcus aureus is a major pathogen in humans and almost everyone has experienced $S$. aureus infections that vary in severity, from food poisoning to mild to severe skin infections that are life-threatening. If $S$. aureus spreads and bacteremia develops, endocarditis, acute hematogenous osteomyelitis, meningitis, and lung infections may occur (Triana et al, 2014). Methicillin Resistant Staphylococcus aureus (MRSA) is a strain of Staphylococcus aureus that is resistant to various antibiotics. MRSA is not only resistant to beta-lactam antibiotics but is also resistant to non-betalactam antibiotics such as macrolides (erythromycin), protein synthesis inhibitors (tetracyclines, chloramphenicol) and quinolones. The antibiotic that is still effective for treating MRSA patients is vancomycin. However, in recent years the incidence of resistance to vancomycin antibiotics has begun to emerge. This resistance can be caused by irrational use of antibiotics and the insertion of a Deoxyribonucleic Acid (DNA) element called Staphylococcal Casette Chromosome mec SCC (Ajrina et al, 2015)

The failure of vancomycin treatment was not due to the failure of the mechanism of action of antibiotics in killing the bacteria, but the changing virulence so that the use of vacomycin for the treatment of MRSA began to be questioned. Although there are many new antibiotics that can be an option in the treatment of MRSA such as linezolid and daptomycin, these new drugs have serious side effects (Hardana et al, 2015). 
The emergence of the phenomenon of resistance to MRSA and the side effects of antibiotics are quite serious, prompting efforts to search for medicinal raw materials from natural ingredients. One of the materials used is dragon fruit stems. Dragon fruit stems are used as an alternative to the development of natural medicinal ingredients, because their availability is quite a lot. In dragon fruit cultivation, so that the stems can bear more fruit, the stems that have already fruited must be pruned, so that the branches do not grow continuously and give rise to new shoots. The stems that have been thrown away are usually only used as a mixture of animal feeds, and the rest is rarely used, so that it piles up as waste. In addition, based on research Sulityarini et al (2020), dragon fruit stems contain flavonoids, saponins and steroids, which make it possible to test their antibacterial activity.

The purpose of this study was to determine the antibacterial activity of ethanolic extract, nhexane, ethyl acetate, and water fractions from dragon fruit stems against the growth of Methicillin-resistant Staphylococcus aureus (MRSA), and to determine the type of compound with antibacterial properties.

\section{Materials and Methods}

\subsection{Materials}

Red dragon fruit stem powder, ethanol 96\%, n-hexane, ethyl acetate, water, Methicillinresistant bacteria Staphylococcus aureus (MRSA), Mannitol Salt Agar media (MSA), Nutrient Broth (NB), NutrientAgar (NA), ciprofloxacin, DMSO, $n$-butanol, acetic acid, glacial acetic acid, formiat acid, water, ammonia, chloroform, dragendorff,chloroform, methanol, anisaldehyde, $\mathrm{H}_{2} \mathrm{SO}_{4}, \mathrm{FeCl}_{3}$ and toluene. Analytical scales (Shimadzu), rotary evaporator (IKA), UV lamp 254, autoclave, laminar air flow, micropipette, yellow tip, cylinder cup, blue tip, test tube, petri dish, trundle term.

\subsection{Method}

This research was conducted in Laboratory of Pharmaceutical Biology B.13 and Laboratory of Pharmaceutical Biology B. 2.1 College of Pharmaceutical Sciences Yayasan Pharmasi Semarang.

\subsection{Extraction method}

Ten (10) gram of Red dragon fruit stem powder (Hylocereus polyrhizus) weighed and macerate with ethanol solvent $96 \%$ with the ratio 1:10 in a closed vessel. The powder is soaked for 3 days while occasionally stirring with daily solvent replacement (repeated). Residues are separated and filtrat is thickened with rotary evaporator and waterbath at a temperature of 40$50^{\circ} \mathrm{C}$ (Puspitasari wt al, 2017).

\subsection{Fractionation method}

Ten (10) gram of red dragon fruit stem extract (Hylocereus polyrhizus) weighed and added with $100 \mathrm{ml}$ aquadest. The mixture is separated in a split funnel and diffractionated with $100 \mathrm{ml} n$ - 
hexane. The n-hexane fraction is accommodated, the water fraction is diffractionated with $100 \mathrm{ml}$ of ethyl acetate. Ethyl acetate fractions and water fractions are accommodated. Each fraction is evaporated over waterbath until concentrated and screened for bioactive coumpound using thin layer chromatography (Rahmawati et al, 2010).

\subsection{Determination of Antibacterial activity}

The anti-bacterial activity was measured using wells method by placing cylinder cup on top of the first layer of MSA media that has been solidified, then poured MSA media that has been suspended with Methicillin-resistant Staphylococcus aureus (MRSA) as much as $10 \mu$ above the media MSA first layer, then allowed to solidify. Cylinder cup is lifted and inserted $30 \mu$ into the well of ethanol extract, $n$-hexane fraction, ethyl acetate fraction and water fraction of red dragon fruit stem (Hylocereus polyrhizus) with concentrations of $20 \%, 25 \%$ and $30 \%$. Ciprofloxacin was used as the positive control while DMSO solution as negative control. The media is incubated $1 \times 24$ hours at a temperature of $37^{\circ} \mathrm{C}$ then measured the diameter of the growth barrier Methicillin-resistant Staphylococcus aureus (MRSA) using a sash term tool (Septiani et al, 2017).

\subsection{Contact Bioautography Test}

Bioautography KLT test is conducted to detect active compounds that have antibacterial activity. Klt plate is attached to $\mathrm{N}$-hexan fraction, ethyl acetate fraction and water fraction. It is then diluted in vessels with the phase of motion of various eluent mixture systems. After that, the delusional KLT Plate is attached to the MSA (Mannitol Salt Agar) media that has been inoculated with MRSA bacteria. Then the KLT plate is silenced for 30 minutes, then the KLT plate is lifted. After that observe if there are spots on the chromatogram characterized by the presence of clear zones that are not overgrown with microbes. further stains that form a bland zone on the KLT plate are sprayed with a spray reagent to determine the type of compound that inhibits (Yumita el at, 2019).

\subsection{Data Analysis.}

The data from clear zone diameter was used in the test TWO WAYS ANNOVA using software SPSS 23. The different results were continued to POST ANNOVA (post hoc) testing. Results are not homogeneous, not normally distributed or not both then conducted statistical analysis of non-parametric tests Kruskall Wallis, and if there are differences continued Mann-Whitney test.

\section{Results and Discussion}

\subsection{Maceration and fractination process}

The maceration process obtained a viscous extract of 24,462 grams with a yield of $9.78 \%$ of 250 grams of powder. Meanwhile, the fractionation process obtained $n$-heksane fraction as much as 1.6 grams with a yield value of $16 \%$, ethyl acetate fraction as much as 1.566 grams with a yield value of $15.66 \%$, and a fraction of water as much as 1.741 grams with a yield value of $17.41 \%$. 


\subsection{Phytochemical analysis}

Powders, pxtracts and fractions of Red Dragon Fruit Stem (Hylocereus polyrhizus) conducted phytochemical screening to conduct qualitative testing of the content of chemical compounds, especially secondary metabolites such as flavonoids, alkaloids, saponins, tannins and terpenoids. Phytochemical screening must meet several requirements, among others simple, fast, can be done with minimal equipment (Yuda et al, 2017).

Test results of color reactions, powders, extracts, n-hexane fractions, ethyl acetate fractions and positive dragon fruit stem water fractions contain flavonoids. Flavonoid compounds are polyphenol compounds that have a number of hydroxy groups so that they tend to be polar Magnesium metal and $\mathrm{HCl}$ react to form bubbles that are $\mathrm{H}_{2}$ gases, while $\mathrm{mg}$ and $\mathrm{HCl}$ metals in this test reduce benzopiron nuclei contained in flavonoid structures so that they form discoloration to red, yellow or orange (Tiwari et al, 2011).

Table 1. Phytochemical analysis from Stem Red Dragon Fruit Extract

\begin{tabular}{|c|c|c|c|c|c|c|c|}
\hline \multirow[b]{2}{*}{$\begin{array}{l}\text { Compound } \\
\text { group }\end{array}$} & \multirow[b]{2}{*}{ React } & \multirow[b]{2}{*}{$\begin{array}{l}\text { Positive results } \\
\text { (library) }\end{array}$} & \multicolumn{5}{|c|}{ Sample } \\
\hline & & & powder & extract & $\begin{array}{c}n \text {-hexane } \\
\text { fraction }\end{array}$ & $\begin{array}{c}\text { Ethyl } \\
\text { Acetate } \\
\text { Fraction }\end{array}$ & $\begin{array}{c}\text { Water } \\
\text { Fraction }\end{array}$ \\
\hline Flavonoids & $\begin{array}{c}\text { Powder } \mathrm{Mg} \\
+\mathrm{HCl}+\mathrm{Amyl} \\
\text { Alcohol } \\
\end{array}$ & $\begin{array}{l}\text { In amyl alcohol is } \\
\text { formed in red, yellow, } \\
\text { orange }\end{array}$ & + & + & + & + & + \\
\hline \multirow{3}{*}{ Alkaloids } & $\begin{array}{c}\mathrm{HCl} 2 \mathrm{~N}, \text { filter }+ \\
\text { Dragendorff }\end{array}$ & Red brick deposits & - & - & - & - & - \\
\hline & $\begin{array}{c}\mathrm{HCl} 2 \mathrm{~N}, \text { filter }+ \\
\text { Mayer }\end{array}$ & $\begin{array}{c}\text { White or yellow } \\
\text { precipitate }\end{array}$ & - & - & - & - & - \\
\hline & $\begin{array}{c}\mathrm{HCl} 2 \mathrm{~N}, \text { filter }+ \\
\text { Bourchardat }\end{array}$ & $\begin{array}{c}\text { Brown to black } \\
\text { precipitate }\end{array}$ & - & - & - & - & - \\
\hline Saponins & $\begin{array}{c}\text { Hot water, } \\
\text { shake+ } \mathrm{HCl} 2 \mathrm{~N}\end{array}$ & Formed a steady froth & + & + & + & + & + \\
\hline $\begin{array}{l}\text { Triterpenoids } \\
\text { / Steroids }\end{array}$ & $\begin{array}{c}\text { Digested with } \\
\text { ether, evaporated } \\
+ \text { acetic acid } \\
\text { anhydrous+ } \\
\mathrm{H}_{2} \mathrm{SO}_{4 \mathrm{p}}\end{array}$ & $\begin{array}{c}\text { A positive red, pink } \\
\text { or purple solution of } \\
\text { triterpenoids. Blue or } \\
\text { green positive } \\
\text { steroids }\end{array}$ & $\begin{array}{c}+ \\
\text { Steroids }\end{array}$ & $\stackrel{+}{+}$ & $\begin{array}{c}+ \\
\text { Steroids }\end{array}$ & $\begin{array}{c}+ \\
\text { Steroids }\end{array}$ & Steroids \\
\hline \multirow[b]{2}{*}{ Tannins } & $\mathrm{FeCl}_{3}$ & $\begin{array}{c}\text { Blue or blackish } \\
\text { green solution }\end{array}$ & - & - & - & - & - \\
\hline & $\begin{array}{c}\mathrm{NaCl} 10 \% \text { +lar. } \\
\text { Gelatine } 1 \%\end{array}$ & $\begin{array}{l}\text { White precipitate } \\
\text { formed }\end{array}$ & - & - & - & - & - \\
\hline
\end{tabular}

The absence of deposits in the Mayer, Dragendorff and Bauchardat tests meant that in dragon fruit stem ethanol extract there were no alkaloids, or the possibility of alkaloid availability in the extract was minimal. The purpose of adding $\mathrm{HCl}$ is because alkaloids are alkaline so they are usually extracted with solvents containing acids. Treatment of extracts with $\mathrm{NaCl}$ before the addition of reagents aims to eliminate proteins. The presence of proteins that settle on the addition of reagents containing heavy metals (Mayer reagent) can give false positive 
reactions in some compounds. Alkaloid screening in principle that is a deposition reaction that occurs due to the replacement of ligands. Nitrogen atoms that have free electron pairs in alkaloids can replace iod ions in dragendroff reagents and mayer reagents (Marliana et al, 2005). In this test no red brick deposits were formed after the addition of dragendroff reagents and no yellow deposits were formed after the addition of mayer reagents. Alkaloids can be found in various parts of plants, but often the levels of alkaloids in plant tissues are less than $1 \%$ (Laurente et al, 2017). This can lead to alkaloid screening tests giving negative results.

The results of color reaction test of saponin compounds showed positive results in powders, extracts, n-hexane fractions, ethyl acetate fractions, and water fractions characterized by the presence of stable froth. The addition of $\mathrm{HCl} 2 \mathrm{~N}$ aims to get a steady and stable foam. Foam arising is caused because saponin compounds contain compounds that are partially soluble in water (hydrophilic) and partially soluble in nonpolar solvents (hydrophobic) as surfactants that can lower surface tension (Laurente et al, 2017). When cornered the hydrophilic group will bind to water while the hydrofob group will bind to the air so as to form a froth.

Saponins are a form of glycosides of sapogenins so they will be polar. Saponins are compounds that are surface active and can cause foam if shaken in water. The onset of foam in saponin tests showed the presence of glycosides that have the ability to form froth in hydrolyzed water into glucose and other compounds. These saponin compounds will tend to be attracted by semi-polar solvents such as ethanol.

The results of terpenoid and steroid tests with a concentrated $\mathrm{H}_{2} \mathrm{SO}_{4}$ reagent are based in principle on the ability of terpenoid compounds and steroids to form color by concentrated $\mathrm{H}_{2} \mathrm{SO}_{4}$. Positive results were given on samples that formed red, orange for triterpenoid analysis and blue or green for steroid analysis (Ergina et al, 2014). The results of the color reaction test of steroid compounds showed positive results on samples of powders, extracts, fractions n-hexane and ethyl acetate fractions of dragon fruit stems indicated by green color on the walls of the cup. While in the water fraction shows negative results because steroid compounds are non-polar compounds that are not soluble in the water fraction which is a polar compound. The addition of anhydrous acetic acid aims to form acetyl derivatives, while the addition of $\mathrm{H}_{2} \mathrm{SO}_{4}$ aims to hydrolyze water that reacts with acetyl derivatives to form a color solution. Discoloration formed due to oxidation in triterpenoid/steroid compounds through the formation of conjugated double bonds. In steroid and triterpenoid testing, the compound was based on the ability of such compounds to form color with concentrated $\mathrm{H}_{2} \mathrm{SO}_{4}$ in anhydrous acetic acid solvents. The results showed no red, pink or purple formation, so it was negarif for terpenoids and formed a turquoise ring so positip contains steroids.

In tannin testing, the addition of $\mathrm{FeCl}_{3}$ did not produce a blackish-green color, so it did not indicate the presence of condensed tannins. While in tannin testing with $\mathrm{NaCl}$ and gelatin not formed white precipitate. This indicates that there is no tannins causing the protein to not settle in the presence of gelatin. Tannins react with gelatin to form a steady copolymer that is insoluble in water. This reaction is more sensitive with the addition of $\mathrm{NaCl}$ to enhance the salting of tannins. 
Table 2. KLT Extract and Stem Fraction of Red Dragon Fruit (Hylocereus polyrhizus)

\begin{tabular}{|c|c|c|c|c|c|c|}
\hline \multirow[t]{2}{*}{ compound } & \multirow[t]{2}{*}{ Reagents } & \multirow{2}{*}{$\begin{array}{c}\text { Positive results } \\
\text { (library) }\end{array}$} & \multicolumn{4}{|c|}{ Results of the study } \\
\hline & & & extract & $\begin{array}{c}\text { faction } \\
n \text {-Heksana }\end{array}$ & $\begin{array}{c}\text { Ethyl } \\
\text { Acetate } \\
\text { Fraction }\end{array}$ & $\begin{array}{l}\text { Water } \\
\text { Fraction }\end{array}$ \\
\hline Flavonoids & $\begin{array}{l}\text { Ammonia } \\
\text { steam }\end{array}$ & $\begin{array}{c}\text { Brownish } \\
\text { yellow stain }\end{array}$ & $\begin{array}{c}(+) \\
\text { yellow } \\
(\mathrm{Rf}= \\
0.96 \\
0.93)\end{array}$ & $\begin{array}{c}(+) \\
\text { yellow } \\
(\mathrm{Rf}=0.93 \\
; 0.85)\end{array}$ & $\begin{array}{c}(+) \\
\text { yellow } \\
(\mathrm{Rf}=0.95 \\
0.90)\end{array}$ & $\begin{array}{c}(-) \\
\text { No stains }\end{array}$ \\
\hline Alkaloids & Dragendroff & $\begin{array}{l}\text { Brown or } \\
\text { orange stains } \\
\text { formed }\end{array}$ & $\begin{array}{c}(-) \\
\text { No stains }\end{array}$ & $\begin{array}{c}(-) \\
\text { No stains }\end{array}$ & $\begin{array}{c}(-) \\
\text { No stains }\end{array}$ & $\begin{array}{c}(-) \\
\text { No stains }\end{array}$ \\
\hline Saponins & $\begin{array}{l}\text { Anisaldehid } \\
\text { - Sulfuric } \\
\text { acid }\end{array}$ & $\begin{array}{c}\text { Blue stains } \\
\text { form - purple } \\
\text { and } \\
\text { sometimes } \\
\text { yellowish }\end{array}$ & $\begin{array}{c}(+) \\
\text { Yellowish } \\
(\mathrm{Rf}= \\
0.76)\end{array}$ & $\begin{array}{c}(+) \\
\text { Yellowish } \\
(\mathrm{Rf}=0.49)\end{array}$ & $\begin{array}{c}(+) \\
\text { Yellowish } \\
(\mathrm{Rf}=0.46)\end{array}$ & $\begin{array}{c}(+) \\
\text { Yellowish } \\
(\mathrm{Rf}=0.69)\end{array}$ \\
\hline $\begin{array}{c}\text { Triter } \\
\text { Penoid/Steroid }\end{array}$ & $\begin{array}{l}\text { Anisaldehid } \\
\text { - Sulfuric } \\
\text { acid }\end{array}$ & $\begin{array}{l}\text { Red-purple, } \\
\text { blue-purple, } \\
\text { green }\end{array}$ & $\begin{array}{c}(+) \\
\text { green } \\
(\mathrm{Rf}=0.17 ; \\
0.15)\end{array}$ & $\begin{array}{c}(+) \\
\text { green } \\
(\mathrm{Rf}=0.96 \\
0.83 ; 0.70)\end{array}$ & $\begin{array}{c}(-) \\
\text { No stains }\end{array}$ & $\begin{array}{c}(-) \\
\text { No stains }\end{array}$ \\
\hline Tannins & $\mathrm{FeCl}_{3}$ & $\begin{array}{c}\text { Blackish-blue } \\
\text { stains } \\
\end{array}$ & $\begin{array}{c}(-) \\
\text { No stains } \\
\end{array}$ & $\begin{array}{c}(-) \\
\text { No stains } \\
\end{array}$ & $\begin{array}{c}(-) \\
\text { No stains }\end{array}$ & $\begin{array}{c}(-) \\
\text { No stains } \\
\end{array}$ \\
\hline
\end{tabular}

TLC test results of flavonoid extract compounds have Rf values of 0.96 and 0.93 , fraction $n$-hexane with Rf of 0.95 and 0.85 , ethyl acetate fraction with Rf value of 0.95 and 0.90 stems of positive red dragon fruit containing flavonoid compounds characterized by the formation of brownish yellow stains after being given ammonia steam patches. This occurs because the reaction of flavonoids with ammonia vapor forms salts and undergoes lengthening of conjugated double bonds so that it will increase the intensity of its color (Mabruroh et al, 2019). TLC test results flavonoid compounds of water fractions showed negative result of flavonoid compounds this occurs differences in results between the preliminary test of phytochemical screening and the affirmation test of TLC, because according to the principle of TLC is a way of separation based on the division of a mixture of two compounds in two phases, namely the mobile phase against the stationary phase in the form of a flat plane. Based on the calculation of the polarity of the chloroform:ethyl acetate phase (60:40) indicating that the phase of motion used is semi-polarnon polar, this indicates that the water fraction of the dragon fruit stem will be held in the stationary phase so that it shows negative results and extracts, ethyl acetate fractions and fractions $n$-hexane dragon fruit stems will be diluted with the mobile phase.

The positive results of the TLC test of alkaloid compounds were shown by forming orange to brown stains after being sprayed using dragendroff. In the TLC extract test, the n-hexane fraction, the ethyl acetate fraction and the dragon fruit stem water fraction did not contain alkaloid compounds. Alkaloids are a group of organic compounds found mostly in nature. All 
alkaloids contain at least one nitrogen atom which is usually alkaline and most nitrogen atoms are part of a heterocyclic ring.

TLC test results showed that the positives containing saponin compounds were extracts with An Rf value of 0.76 , a fraction of $n$-hexane with an $\mathrm{Rf}$ value of 0.49 , an ethyl acetate fraction with an $\mathrm{Rf}$ value of 0.46 and a water fraction with an $\mathrm{Rf}$ value of 0.69 . This is because saponins are triterpene glycosides that have glycosyl groups that serve as polar groups so that the compound can be soluble in extracts, ethyl acetate fractions and water fractions that have polar properties. Patching used is anisaldehida- $\mathrm{H}_{2} \mathrm{SO}_{4}$ to produce stains of blue to purple color and sometimes yellowish indicates the presence of saponin content.

TLC test results of steroid compounds obtained positive results on extracts with Rf values of 0.17 and 0.15 and fraction $n$-hexane with $\mathrm{Rf}$ values of $0.96 ; 0.83$ and 0.70 . It is characterized by the appearance of purple stains after spraying patches of anisaldehid - sulfuric acid. According to. Steroid is a compound composed of a long chain of hydrocarbonS $\mathrm{C}_{30}$ that causes steroids to be non polar so as to give negative results on the ethyl acetate fraction and water fraction.. This is a difference in the results between the preliminary test of phytochemical screening and the klt affirmation test, because according to the principle of TLC is a way of separation based on the division of a mixture of two compounds in two phases, namely the phase of motion against the stationary phase and the mobile phase in the form of a flat plane. Based on the calculation of the polarity of the toluene:ethyl acetate phase (93:7) indicating that the mobile phase used is non polar, this indicates that the ethyl acetate fraction and the water fraction of the dragon fruit stem will be held in the stationary phase so that it shows negative results and the extract and fraction n-hexane of the dragon fruit stem will be diluted with the mobile phase.

TLC test results of tannin compounds showed negative results on extracts, fractions $n$ hexane, ethyl acetate fraction and water fraction because no blackish blue stain formed after adding $\mathrm{FeCl}_{3}$. Phenolic group from tannin compound will react with $\mathrm{FeCl}_{3}$ and form a complex blackish blue color.

\subsection{Antibacterial activity}

The results of the measurement of the diameter of the clear zone, showed the n-hexane fraction has the greatest antibacterial activity than extracts, ethyl acetate fractions, water fractions. It is possible to contain more antibacterial compounds in the H-hexan fraction. According to Yumita et al (2019) antibacterial activity depends on the type of microorganisms, gram positive or gram negative, especially the structure of cell walls and outer membranes. Differences in cell wall structure determine the penetration and activity of antibacterial compounds. MRSA bacteria are gram-positive bacteria, whose cell wall components are polar while the N-hexan fraction is a non-polar fraction, making in theory its diffusion ability more difficult. However, the solvent used is DMSO (dimethyl Sulphooxide), so this is minimized so that the N-hexane fraction has the maximum ability to enter the cell. DMSO is a polar aprotic

solvent that dissolves with both polar and non-polar compounds and also dissolves in organic solvents such as water (Laurente et al, 2017). 
The results of the Post Hoc Inter-Treatment Test Interpretation showed that all concentrations tested differed significantly, except in extract treatment $25 \%$ with $\mathrm{N}$-hexane fraction $20 \%$, and $\mathrm{N}$ - hexane fraction $20 \%$ with ethyl acetate fraction $30 \%$. This indicates that the fractionation process gives a more effective result, due to the separation of groups of compounds that are antibacterial, so that the antibacterial ability is greater, except in the two different treatments are not significant. Based on the results of this test, it is necessary to do the process of separation of antibacterial compounds to the isolation stage, to know the potential of antibacterial active compounds from dragon fruit stems. Therefore, it is necessary to conduct tests to find out what compounds from dragon fruit stems have the ability as antibacterial, through contact bioautography tests.

Table 3. Data On Average Diameter of Ethanol Extract, Fraction n-Hexane, Ethyl Acetate Fraction, and Red Dragon Fruit Stem Water Fraction (Hylocereus polyrhizus) Against Methicillin-resistant Staphylococcus aureus Bacteria (MRSA)

\begin{tabular}{cccccc}
\hline \multirow{2}{*}{ Sample } & \multicolumn{3}{c}{ Average Clear zone diameter (cm) } \\
\cline { 2 - 6 } & $\mathbf{2 0 \%}$ & $\mathbf{2 5 \%}$ & $\mathbf{3 0 \%}$ & $\mathbf{K}(+)$ & Control \\
\cline { 2 - 6 } & 1.554 & 1.684 & 1.850 & 2.152 & 0.000 \\
\hline Extract & 1.666 & 1.820 & 1.948 & 2.146 & 0.000 \\
\hline $\boldsymbol{n}$-Heksane Fraction & 1.358 & 1.466 & 1.640 & 2.180 & 0.000 \\
\hline $\begin{array}{c}\text { Ethyl Acetate } \\
\text { Fraction }\end{array}$ & 0.578 & 0.670 & 0.884 & 2.148 & 0.000 \\
\hline Water Fraction & & & & & \\
\hline
\end{tabular}

Table 4. Results of Post Hoc Test Interpretation Between Treatment Groups

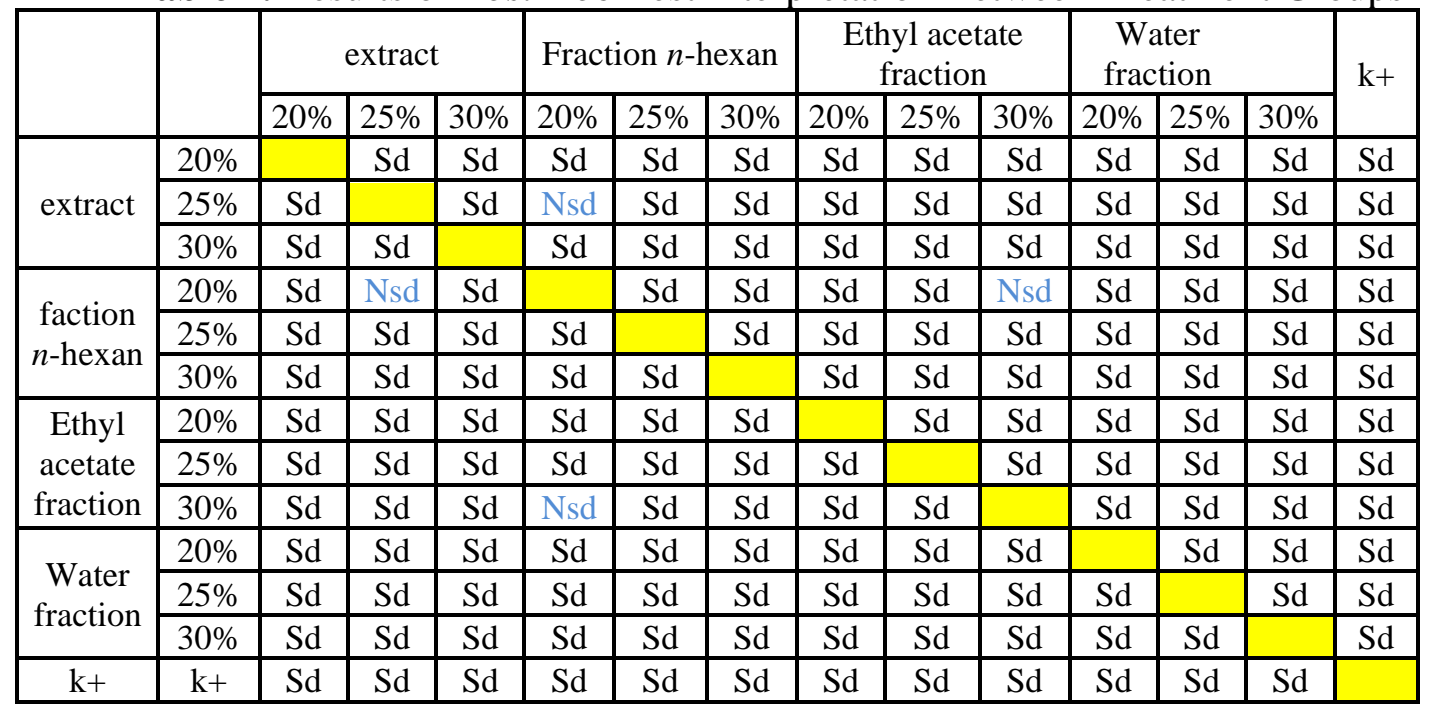

Information:

Sd : Significant Differences

Nsd : No Significant Difference 


\subsection{Bioautografi result}

The results of the contact bioautography shown in table 5 can be known that flavonoids and saponins are good on extra, N-hexan fraction, ethyl acetate and water potentially as antibacterial compounds of dragon fruit stems. While in the triterpenoid fraction only in extracts and N-hexan fractions alone are able to show its ability as an antibacterial. This is biased due to the influence of solvents i.e. ethyl acetate and water, which are polar, while terpenoids are nonpolar, causing very little amount of methyl acetate, perhaps even non-existent. This is why terpenoid compounds in ethyl acetate and water fractions are unable to produce antibacterial activity.

Table 5. Bioautography Test Results Contact Extracts and Stem Fractions of Red Dragon Fruit Against Methicillin-resistant Staphylococcus aureus (MRSA) Bacteria

\begin{tabular}{ccccc}
\hline Compound & extract & $\begin{array}{c}\text { faction } \\
n \text {-hexane }\end{array}$ & $\begin{array}{c}\text { faction } \\
\text { Etil acetate }\end{array}$ & $\begin{array}{c}\text { faction } \\
\text { water }\end{array}$ \\
\hline Flavonoids & + & + & + & - \\
Alkaloids & - & - & - & - \\
Saponins & + & + & + & + \\
Triterpenoids & + & + & - & - \\
Tannins & - & - & - & - \\
\hline
\end{tabular}

\section{Conclusion}

Extracts, fractions $n$-hexane, ethyl acetate fraction and water fraction of red dragon fruit stem (Hylocereus polyrhizus) have antibacterial activity against the growth of methicillinresistant bacteria Staphylococcus aureus (MRSA). There is a difference in antibacterial activity between extracts, fractions of $n$-hexane, ethyl acetate fractions and water fractions of red dragon fruit stems (Hylocereus polyrhizus) at concentrations of 20\%, 25\%, 30\% against Methicillinresistant Staphylococcus aureus (MRSA) bacteria,except at n-hexane fraction 20\%with 25\% extract. Group of compounds that have antibacterial activity in extracts and fractions of ethyl acetate stems of red dragon fruit are flavonoids, saponins and steroids.. The group of compounds there fraction ofethyl acetate is flavonoids and saponins and the water fraction contains only saponins.

\section{Conflict of Interest}

All Authors declare no conflict of interest and agree with the content of the manuscript.

\section{References}

Ajrina LBP, Dharmana E, Hadi P. Effect Of Nigella Sativa Oil Administration And Its Combination With Seftriakson On The Number Of Germs Methicillin Resistant Staphylococcus Aureus ( Mrsa) On Liver Culture Mencit Balb / C. Media Med Muda. 2015;4(4):307-16. 
Astarina K, Astuti K, Warditiani N. Phytochemical Screening of Methanol Extract of Rhizome Bangle (Zingiber purpureum Roxb). 2012;(2009):150-4.

Ergina, Nuryanti S P, Pursitasari I. Qualitative Test of Secondary Metabolite Compounds on Palado Leaves (Agave angustifolia) Extracted with Water Solvents and Ethanol. J Akad Kim. 2014;3(3):165-72.

Hardana H, Citizen E, Medicine F, Lampung U, Microbiology B, Medicine F, et al. Pomegranate Extract As Antibiotic For MRSA Infection Treatment. The majority. 2015;4:83-7.

Laurente MR, Adegoke JA, Ademakinwa EA, Carlo J, Afable C, Aguam DH, et al. Qualitative Phytochemical Screening of Selected Medicinal Plant Species of the Philippines. JAASP. 2017;6(1):10-4.

Mabruroh EQ, Mursiti S, Kusumo E. Isolation and Identification of Flavonoid Compounds from Mulberry Leaves (Morus alba Linn). Indonesia J Chem Sci. 2019;8( 1):16-22.

Marliana Elementary School, Suryanti V, Suyono. Phytochemical Screening and Analysis of Thin Layer Chromatography Of Chemical Components of Siamese Pumpkin Fruit ( Sechium edule Jacq . Swartz.) in Ethanol Extract. Biopharmaceuticals. 2005;3(1):26-31.

Puspitasari AD, Prayogo L. Total Phenolic Levels of Kersen Leaf Ethanol Extract (Muntingia Calabura). J Ilm Scholar Of Exakta. 2017;1-8.

Rahmawati I, Noviana S, Rinanto Y. Antifungi Activity Test Fraction n-Heksan, Ethyl Acetate, and Water from Papaya Leaves ( Carica Papaya Linn .) against Candida albicans ATCC 10231 Antifungal Activity Test of n-Hexane, Ethyl Acetate, and Water of Papaya Leaf. $J$ Farm Indones. 2010;7(1):30-4.

Saudale F, Boelan E, Boelan E. Antibacterial Activity Of Polar Extract And Non Polar Moringa Seeds (Moringa Oleifera) From Timor Ntt Island. Jst (Journal of Science and Technology). 2018;7(1):67.

Septiani, Dewi EN, Wijayanti I. Antibacterial Activity Of Seagrass Extract (Cymodocea Rotundata) Against Staphylococcus Aureus Bacteria And Escherichia coli (Antibacterial Activities of Seagrass Extracts (Cymodocea rotundata) Against Staphylococcus aureus and Escherichia coli). SAINTEK Perikan Indones J Fish Sci Technol. 2017;13(1):1.

Sulistyarini I, Sari AD, Wicaksono TA. Phytochemical Screening of Secondary Metabolite Compounds of Dragon Fruit Stems... (Sulistyarini, et al.). J Ilm Scholar Of Exakta [Internet]. 2020;5:56-62. Available from: https://publikasiilmiah.unwahas.ac.id/index.php/CE/article/view/3322

Tiwari P, Kumar B, Kaur G, Kaur H. Phytochemical Screening and Extraction: A Review. Int Pharmaeutica Sci [Internet]. 2011;1(1):98-106. Available from: file:///D:/Jurnal MRSA/Prashant Tiwari Phytochemical.pdf

Triana D, Medicine P, Bengkulu U. Frequency $\beta$-Lactamase Results Staphylococcus aureus Iodometrically In Microbiology Laboratory Faculty of Medicine Andalas University. A Gradient. 2014;10(2):992-5.

Yuda PESK, Cahyaningsih E, Winariyanthi NLPY. *Saraswati Pharmacy Academy Denpasar, Cambodia Street No 11A, Denpasar, Bali. Medicamento. 2017;3(2):61-70.

Yumita, Razak AR, Indriani, Bahri S. Analysis Of Klt Bioautography Of Bark Extract Of Java Wood Plant Stem (Lannea Coromandelica) Against Staphylococcus Aureus Bacteria And Shigella dysentriae. KOVALEN J Ris Kim. 2019;5(2):191-6. 